\title{
Symbolic Closure through Memory, Reparation and Revenge in Post-conflict Societies
}

Brandon Hamber

Richard A. Wilson

University of Connecticut Human Rights Institute, richard.wilson@uconn.edu

Follow this and additional works at: https://opencommons.uconn.edu/hri_papers

Part of the Public Policy Commons

\section{Recommended Citation}

Hamber, Brandon and Wilson, Richard A., "Symbolic Closure through Memory, Reparation and Revenge in Post-conflict Societies" (2002). Research Papers. 5.

https://opencommons.uconn.edu/hri_papers/5 


\title{
Symbolic closure through memory, reparation and revenge in post-conflict societies
}

\author{
(c) Brandon Hamber \& Richard Wilson \\ Published in Journal of Human Rights Vol. 1, No. 1, March 2002 \\ ISSN 1475-4835 www.wellesley.edu/journalofhumanrights. Taylor and Francis \\ www.tandf.co.uk/journals
}

\begin{abstract}
Countries going through democratic transition have to address how they will deal with the human rights crimes committed during the authoritarian era. In the context of amnesty for perpetrators, truth commissions have emerged as a standard institution to document the violent past. Increasingly, claims are made that truth commissions have beneficial psychological consequences; that is, that they facilitate 'catharsis', or 'heal the nation', or allow the nation to 'work through' a violent past. This article draws upon trauma counseling experience and anthropological fieldwork among survivors to challenge these claims in the context of the South African Truth and Reconciliation Commission. It argues that nations are not like individuals in that they do not have collective psyches, that nation-building discourses on reconciliation often subordinate individual needs, and that truth commissions and individual processes of healing work on different time lines. Calls for reconciliation from national leaders may demand too much psychologically from survivors, and retribution may be just as effective as reconciliation at creating symbolic closure.
\end{abstract}

Keywords: South Africa, Truth and Reconciliation Commission, symbolic closure, memory

We are meant to be a part of the process of the healing of our nation, of our people, all of us, since every South African has to some extent or other been traumatised. We are a wounded people...We all stand in need of healing (Archbishop Desmond Tutu in his opening address to the South African Truth and Reconciliation Commission on December 16, 1995).

The South African Truth and Reconciliation Commission (TRC)(1) has become the paradigmatic international model of how to 'work through' a violent past and in so doing, to 'heal the nation'. Increasingly it is being argued that countries which have undergone large scale conflict such as Bosnia, Rwanda and Northern Ireland need to set up similar truth commissions. A country-wide process of revealing and confirming past wrongs is said to facilitate a common and shared memory, and in so doing create a sense of unity and 
reconciliation. By having this shared memory of the past, and a common identity as a traumatised people, the country can, at least ideally, move on to a future in which the same mistakes will not be repeated.

Yet the idea of dealing with the past through a national truth commission ascribes a collective identity to a nation, and assumes that nations have psyches that experience traumas in a similar way to individuals. This act of 'psychologising the nation' mistakenly implies that the pursuit of national unity is a unitary and coherent process, and that individual and national processes of dealing with the past are largely concurrent and equivalent.

This chapter assesses the psychological impact on victims of the nation-building discourse of truth commissions. It asks, to what degree does a nation undergo a uniform and collective truth-telling experience? What are the consequences for individual subjectivities of asserting that nations have psyches or collective consciences? This chapter argues that psychologizing the nation can be an ideology for subordinating diverse individual needs to the political expediency of national unity and reconciliation. Truth commissions aim to construct memory as a unified, static and collective object, not as a political practice, or as a struggle over the representation of the past that will continue to be vigorously contested after their existence.

The discussion draws attention to a range of post-conflict societies (or those in some sort of political transition) and explores the many divergences between individual psychological processes and national processes of remembering such as truth commissions. We conclude that the nation-building discourse of truth commissions homogenize disparate individual memories to create an official version, and in so doing they repress other forms of psychological closure motivated by less ennobled (although no less real) emotions of anger and vengeance. Claims to heal the collective unconscious of the nation therefore mask how truth commissions both lift an authoritarian regime of denial and public silence, as well as create a new regime of forgetting which represses other memories and forms of psychological closure.

\section{JUXTAPOSING NATIONAL AND INDIVIDUAL TRAUMA}

Nations do not have collective psyches which can be healed, nor do whole nations suffer post-traumatic stress disorder and to assert otherwise is to psychologize an abstract entity which exists primarily in the minds of nation-building politicians. Nevertheless, it is remarkable how widely accepted this nationalist language is in the literature on truth commissions and post-Communist truth-telling. It is almost as if because nationalist discourse is contained within human rights talk, then it cannot be in any way misguided or destructive. However, the mythology of nation-building can have damaging consequences 
for individual survivors who are seen as 'out of step' with a putative collective conscience.

Michael Ignatieff challenges the notion of national psyches when he writes:

We tend to vest our nations with conscience, identities and memories as if they were individuals. It is problematic enough to vest an individual with a single identity: our inner lives are like battlegrounds over which uneasy truces reign; the identity of a nation is additionally fissured by region, ethnicity, class and education [Ignatieff, 1998, p. 169].

Instead of reconstructing the national psyche and healing the nation, Ignatieff argues that truth commissions can only provide a frame for public discourse and public memory. They can help to create a new public space in which debate and discussion on the past occurs. Beyond this they can do little, although they can be useful if they present the past as an irresolvable argument that is to be continually debated. This is not wholly open-ended, as they must also define the acceptable limits of the argument over what happened to whom and reduce the range of permissible historical revisionism. Within the context of public discourse, the past is subject to infinite debate where memory is not a fixed object, but the social practice that constitutes narratives on the past.

At the level of the subject, victims' expectations and desires can converge with the efforts of national truth commissions, which can legitimate the multiplicity of voices that make up the national debate on the past. The legitimating function of this new framing of history is important because during the authoritarian era such narratives are regularly silenced and deformed by the media, the courts and public institutions. Truth commissions and other processes to establish new truths (for example, commissions of enquiry) can create public spaces in which survivors can articulate their individual narratives. Their voices are heard often for the first time by a national audience, many of whom previously claimed they did not know about the violent past. After the extensive media coverage of a truth commission, the argument that atrocities did not occur can never again be made - the range of licit truths (and lies) is, in this way, irrevocably narrowed.

Yet if we look hard, we start to see cracks appearing between the national and individual representation of trauma, if only because there is a "truth that can be known only by those on the inside" (Ignatieff, 1998, p. 175) and that the truth itself is highly personalised.

Michael Lapsley (1997, p. 46), priest and facilitator of the Healing the Memory Workshops, in South Africa, argues that "memory can be healed" by individuals. To this end individuals need to talk about their distinctive pasts, put their memories on the table, open them up, clean them out and in so doing facilitate healing. Apart from his rather outdated 'suitcase' metaphor of memory, Lapsley does capture the uniqueness of individual acts of remembering, and the need for a diversity of memory processes outside of national commissions. 
The Healing the Memory Workshops are independent of the South African TRC and provide a structured forum in which individuals can constitute a new identity by gazing upon the past in a highly personalised way. The South African TRC in itself did provide some of these functions through its hearings process, and was a psychologically healing process insofar as it provided a space for memory work to occur. It was also useful in that it created the context and new legitimate space for endeavours such as Lapsley's workshops.

Nevertheless, recent history from Latin America teaches us that the establishment of a truth commission in itself is not enough to meet the psychological needs of individuals - they may be necessary first steps toward individual psychological healing but they are generally not sufficient in themselves (see Hamber, 1995).

Survivors and the victims for whom they grieve both inhabit a liminal space, which is both part of society but removed from society; it could be called an experience of 'the living dead'. This space is characterised by uncertainty and doubt, and is caused, according to Freud, by survivors' experiences of the uncanny. Survivors' needs for closure and symbolic reintegration, (that is, an end to a state of uncertainty and liminal status) may work in different ways to those enshrined within national commissions. Truth commissions can assert an over-simplistic view of what it takes to move on from the past. Importantly, it should not be assumed too easily, as the banners displayed by the TRC did, that "Revealing is Healing" (Hamber, 1998, p. 83). Hayes writes, "Just revealing, is not just healing. It depends on how we reveal, the context of the revealing, and what it is that we are revealing" (Hayes, 1998, p. 43). Thus, remembering, in itself, is not necessarily a directly redemptive and liberating practice, and is only one of many possible routes to symbolic closure for survivors. By 'closure' we mean a situation where the trauma is no longer seen as unfinished business, requiring, for instance a compulsion to take revenge. Grief and loss no longer plague the individual consciously or unconsciously, and the victim lives not in a state somewhere between denial and obsession, where the loss is to a large degree accepted and incorporated into the functioning of everyday life.

Furthermore commissions, since they are often transitory and last at best only a few years, may seek forms of closure which are only partial. Truth commissions often operate on a time frame which is highly curtailed and limited, and which requires a premature process of dealing with the past from survivors of atrocities for whom the process of grieving often lasts a lifetime. 'Truth' in the sense of speaking about the past and having one's version recognised, is but one of the many possible forms of closure for the individual. Processes aimed at closure are also inherently contradictory in their nature. Reparations provided through truth commission processes or after formal enquiries, for example, can aid closure but can also be viewed as problematical by some victims who may be uncomfortable with accepting what they perceive as 'blood money'. Arguably, revenge could also serve the function of closure for the individual; a possibility wholly excluded and deemed outside the acceptable range of discourse of the South African TRC. Equally, revenge could also serve 
as a way of perpetuating violence and in so doing trap the individual in the liminal space.

The rest of this chapter addresses how truth commissions seek symbolic closure and how the limited procedures adopted converge or diverge with survivors' individual agendas. We will argue that truth commissions (and other projects to rewrite the official version of the past) and individuals proceed along different temporal continuums when dealing with violence and trauma. This chapter shows how different processes embodied in individual trauma work, national history-making, and reparations offered by truth commissions. These interact and shape one another, and at times are mutually reinforcing while at other times they are disharmonious and incongruous.

\section{THE MEANING OF REPARATIONS AND ACKNOWLEDGEMENT (2)}

Another arena of societal struggles over memory centres on the physical markers of past violence and repression. Monuments and museums, plaques and other markers are some of the ways in which governments as well as social actors try to embody memories. Other social forces, meanwhile, try to erase and transform these physical markers, as if by changing the shape and function of a place one can banish it from memory [Jelin, 1998, p. 26].

Reparations are one of the main means by which truth commissions and similar processes seek to achieve national and individual reconciliation, and they result in common psychological consequences in each case. Psychologically speaking, the so-called symbolic acts of reparation(3) such as reburials, and material acts of reparation such as payments, serve the same end. Both these forms of reparation can, although not necessarily, play an important role in processes of opening space for bereavement, addressing trauma and ritualising symbolic closure. They acknowledge and recognise the individual's suffering and place it within a new officially sanctioned history of trauma. Symbolic representations of the trauma, particularly if the symbols are personalised, can concretise a traumatic event, and help re-attribute responsibility. The latter stage is important because labelling responsibility can appropriately redirect blame towards perpetrators and relieve the moral ambiguity and guilt survivors often feel.

Reparations, symbolic or otherwise, can serve as focal points in the grieving process, and this can aid recovery by allowing individuals to focus exclusively on their grief. Survivors often unconsciously turn to institutions such as truth commissions, the criminal justice system or community/traditional justice processes as a context in which they externalise their grief and seek to come to terms with it. The symbols of public or collective ritual, and material reparations in some instances, can mark the point of moving onto a new phase and represent an individual's mastery over the past. On a macro level extensive social processes like truth commissions can represent a new willingness by the state or civil society institutions to exhume the buried issues of the past through. This can occur metaphorically 
or literally, as when truth commissions recover the hidden physical remains of the disappeared.

Unfortunately, no matter how well meaning, all reparations strategies and governmental commissions face the same, albeit obvious, intractable problem. Acknowledgement, apology, recognition, material assistance, a perpetrator's confession and even exhuming the bodies/bones of the 'missing' can never bring back the dead or be guaranteed to converge with, and ameliorate, all the levels of psychological pain suffered by a survivor. Memory work revisits the past as an alienated tourist, and its attempts at recovery are constantly undermined by both the fractured nature of lived memory and the irrecoverability of time. The trauma and accompanying senses of injustice, anger and hurt, which lie in the depths of the actor's psyche, are both immeasurable and ineffable. Furthermore, recovery from trauma is obstructed by the unlikelihood of justice in many societies in transition. This is typified by the South African TRC's amnesty process that grants indemnity from civil and criminal proceedings to perpetrators who confess to political crimes; and more dramatically where blanket amnesties have been granted to perpetrators as occurred in Chile, Argentina, Brazil, Guatemala and a number of African countries.

Thus reparation (and all action undertaken by a truth commission) has ambivalent psychological consequences for survivors - public acknowledgement of social truths and monetary compensation are valuable contributions, but they can never wholly meet all the psychological needs of the survivors as these are disparate, inchoate and contradictory. The result is that in the aftermath of large-scale political violence, we should expect to have to live with the unsatisfied demands (for their own versions of truth, justice, compensation, and so on) of survivors for a long time. Truth commissions, with their focus on speaking about and writing a revised account of the past, are at best only the beginning of a set of linked processes which may lead to symbolic closure for some individuals.

\section{LIMINALITY AND REINTEGRATION}

To better understand the impact of nation-state attempts at reconciliation through reparations, truth commission reports and the like, we have to return and look more closely at survivors' experiences of trauma caused by political violence. Trauma and violence shatter individual cognitive assumptions about the self and the world. Severe forms of trauma shatter the cognitive assumptions of personal invulnerability, viewing oneself positively and that the world is a meaningful and comprehensible place (Janoff-Bulman, 1985).

Trauma often results in confusion, and an inability to fully understand the causes of one's suffering. This 'bafflement' grows out of a negative encounter with the authoritarian state which deforms rationality and foments personal and social chaos and an attendant fragmenting of the self (Neal, 1998, p. 6). As a result of trauma and a state-sponsored regime 
of denial, basic questions are raised and remain unanswered, such as, how and why did the event happen and what is going to happen next (ibid., p. 201)? The confusion and bafflement following a trauma, and the shattering of cognitive assumptions about the world, are exacerbated when the markers of the past that give it its coherence, such as the existence and compassion of loved ones, are destroyed or rendered invisible. This is particularly the case with regard to political disappearance that thrusts an inordinate amount of unanswered (and technically unanswerable) questions upon the survivor. The personal perplexity and incoherence of the trauma is extreme in the case of political disappearances.

Suarez-Orozco (1991) has written about such issues with respect to Argentina, and he documents how disappearances and the lack of bodies to be buried creates an ontological uncertainty among survivors and a psychological experience of what Freud termed the uncanny. This notion captures the common difficulties experienced by survivors who must mourn without a corpse: "The uncanny feeds on uncertainty (Is he/she alive? Is he/she dead?)" (ibid., p. 491). As a result, in Argentina, mummification took on epidemic proportions following disappearances, where the bedrooms and offices of the disappeared were kept as they were at the time of the disappearance, while the living waited for their return (ibid., p. 490). Similarly, in Brazil some families even refuse to move house in case their missing relatives finally come home.(4) In Northern Ireland, some of the families of the disappeared(5) have not cleaned out the rooms of their missing relatives - despite the fact that the last political disappearance happened in the early 1980s.(6)

Both the survivor and the dead inhabit a symbolically liminal social space. Both are part of society but removed from society. This is captured in the words of a relative of the disappeared in Northern Ireland, when he says, "We have been left hanging in space. There are people who know exactly where the disappeared are. Why doesn't somebody tell us where they are?"(7) In South Africa, survivors and the families of victims reiterate the same haunting cry, "If they can just show us the bones of my child, where did they leave the bones of my child?"(8) The full horror of the liminal space is most poignantly captured by Mathilde Mellibovsky in a book entitled A Circle of Love Around Death, about the mothers of the disappeared in Argentina. She writes:

I do not imagine hell as beds with shackles where the condemned must lie, but rather as a couple of easy chairs in which one can sit comfortably and wait for the postman to bring news - which will never come [in Bronkhorst, 1995].

Experiences of the uncanny can be exacerbated by the responses of government officials. Relatives of those arrested or disappeared, particularly in Latin America, Eastern Europe and South Africa, would search in local jails, police stations, and morgues, but would often receive little information. In many cases, relatives looking for the disappeared were given a run around by authorities from one police station to another. Authorities would deny any knowledge of their fate, and leave writs of habeas corpus unanswered. As Malin (1994:197) 
writes of the uncertainty generated in the Latin American context:

In denying knowledge or responsibility for the disappearances, the state created a system in which their victims seemed to have never existed at all. Habeus corpus does not work for the simple reason that there is 'no corpus'. No cuerpo. No body.

In South Africa, the police often told families that their children had left the country to join the liberation movement armed forces in exile. This was, in some cases, true - but in others was a cover up for a security force disappearance and murder. This left many families in an uncanny space in which they believed (or at least hoped) that their loved ones were in exile and would return once liberation was achieved. Joyce Mtimkulu, who lived in hope for eight years that her son was in exile, captures the uncertain feelings around this. She says:

The release of Mandela to me was the loss of my son because he should have come back with others...that hope that everybody is coming back home, the other people got happy about that, but to us it was the moment of tears because our son never came back [see Endnote 8].

In many cases in Latin America, the security forces, in a Kafkaesque twist, would seize and destroy all identification papers of their victim and then deny that they had ever existed. Security police and the military intentionally promoted the unreality of death by making the victim's body vanish and then wiping away any official record of the victim's existence.(9) This eradication of the identity of the victim would leave survivors in a state of profound ontological insecurity.

Political disappearances around the world appear to have different gender effects. Most commonly, it is the female relatives of victims who are most vocal about being forced into a liminal space along with their relatives. Ramphele (1996) has analysed in detail how in South Africa widowhood places women into a liminal phase and a state of ambiguity that is symbolically marked. Political widows became the embodiment of social memory about the fallen hero and social ambiguity is inscribed onto their bodies during this state. In Sotho and Tswana communities, the body of the widow is marked in ways which express a fear of ritual dangers: her head is shaved, her body is smeared with charcoal and herbs, her face is covered with a black veil (Pauw, 1990). Occasionally a widow wears her clothes inside out, or only one shoe. She does not eat off of everyday utensils and must stay out of the public arena. Silence becomes a marker of liminal status.

Unfortunately, however, the reality is that the material symbol (usually the body) that is necessary for moving out of the liminal space is seldom recovered after large-scale political violence. In these cases in South Africa, the truth commission became the next best (or the least worst) option, as it attempted to at least corroborate some information about what 
happened to disappeared individuals.

\section{PUBLIC TESTIMONY AND SYMBOLIC CLOSURE}

How does testifying at hearings relate to feelings of the uncanny and liminality? Speaking at public hearings like those of the South African TRC can break an enforced silence and represent a point of closure and transition in the grieving process, through interacting with the national symbolic process of the TRC. The widow, in Ramphele's sense, leaves behind her grieving phase, shedding the symbols of her liminality. In its reparations policy (which may include personal monetary reparation and symbolic forms like tombstones or monuments), the TRC creates possibilities for the internalisation of loss and Freud's work of mourning (trauerarbeit) that does not exist through legal channels.(10) Without a corpse or a conviction it was often not possible to get compensation legally, but through the TRC it was much easier to obtain a finding (recognition of loss or suffering) and to obtain reparations (symbolic compensation for the loss).

One case which demonstrates a survivor's experience of uncertainty and her quest to resolve liminality through legal and TRC channels is that of Susan van der Merwe of Potchefstroom, a teacher and mother of five. Susan van der Merwe was married to a white farmer who went missing at Buffelsdrift, at the border post between South Africa and Botswana on 1 November 1978. Susan van der Merwe reported at the TRC hearings in Klerksdorp in September 1996 the same kinds of deep uncertainty as documented by Suarez-Orozco for victims in Argentina, "my whole life was then an uncertainty... and this uncertainty hung over us like a dark cloud. It left such an immense, indescribable feeling of a vacuum that you cannot explain it to anyone else. One's life, your whole life is incomplete".(11) The uncertainty surrounding her husband's disappearance was worse than knowing that he was dead and placed the family in a liminal state. The two children at university were 'deeply disturbed' and failed their term exams. This state of liminality was material and financial, as well as psychological. Since Susan van der Merwe had no official evidence of her husband's death, she could not conduct financial transactions and she was not able to secure loans to buy a house or pay for her children's' university costs. She said:

At the beginning of 1979, the two children wanted to go and reregister at the university but the bank manager informed me that I did not have any security. The circumstances were that I was completely dependent on my husband. He ran on the financial matters...It never occurred to me that because of the way in which my husband had died, that if there were any funds available from him, that it would have been taken away from me because we were not married in community of property [see Endnote 11].

Prior to the TRC the case was investigated by the security police and four years later, in 1982, the Supreme Court established the events around the farmer's disappearance. Through the evidence of a police informer 'Mr. X', the court heard how four umkhonto we 
sizwe (MK)(12) combatants had been walking along the road to Thabazimbi, when van der Merwe stopped and offered them a lift to the next town. Once in the car, the MK cadres pulled out guns and forced the farmer to drive in the opposite direction and they used his car to transport goods. They then walked Mr. Van der Merwe out into the bush and executed him, and drove his car to the border. One MK cadre led police to the scene, but the body was never found.

For the family of the farmer, the court case resolved only some of their questions. "After these findings, the Supreme Court certified my husband as dead, and this left my children in another vacuum of uncertainty. Why was such a horrendous deed done to my husband which cost him his life? For what purpose, what were they hoping to achieve by that (see Endnote 11)?" Susan van der Merwe never got the answers to those questions from her husbands' killers, yet, despite opposition from her conservative white community on the West Rand, she explicitly stated that speaking in public in itself was important to her. She needed to present her story and wrestle with its inconsistencies publicly and also to affirm her renunciation of a past of racialised violence.

In the case of Susan van der Merwe, and many others like it, we see how the pursuit of truth through the courts and TRC became a way of addressing loss publicly. According to SuarezOrozco (1991), by pursuing their crusade for justice, the Madres of the Plaza de Mayo(13) similarly internalised their loss. Thus national institutional processes (such as truth commissions and the justice system) are, at least in certain ways, closely bound up with individual psychological processes. The TRC in South Africa, at least to some degree, became a mode of psychological repair, where denial could be superseded and both work of mourning (transition out of uncertainty and liminality) and narrative fetishism (teleologising and attaching transcendental meaning to loss) could take place. Both are ways in which individuals reconstruct their social identities through forging a meaningful and coherent narrative in the wake of trauma. The TRC thus became a mechanism through which ideological rationalisations for loss could be internalised. Suffering became meaningful by associating it with the teleology of the liberation struggle and the universal redemption of reconciliation.

In some instances even more minimal forms of recognition by the TRC can be useful and move the individual toward closure. Sandra Peake, co-ordinator of the WAVE Counselling Centre in Belfast, says it is only over the last year, as the peace process has moved forward, that some of the families of the disappeared in Northern Ireland have started to clean out the rooms of their missing relatives and get rid of their clothes. She feels that this subtle change has come about because of the moves toward peace and the recognition in 1995, and onwards, that there are in fact disappeared persons in Northern Ireland (see Endnote 6).

However, based on our comparative analysis of several countries, it is evident that for most people more is needed than simple recognition and acknowledgement. The body itself, and 
the process of grieving around it, is of significance in most cultures. In Northern Ireland it is common for the families of the disappeared to stress the importance of a "proper and decent Christian burial'.(14) The rituals that take place around the bodily remains aid closure and, without the body, closure seems all the more improbable. In this regard, Sandra Peake points out the importance of the Irish wake and the ritual significance of sitting up all night with the corpse (see Endnote 6). If this is not possible because the body is truly gone, she says, the only other strategy that can bring some closure for the relatives is the revealing of the facts about the disappearance and why the person was taken in the first place. This stresses again that a truth recovery process (for example, the South Africa TRC, a formal inquiry, and so on) remains the only, albeit limited, hope for having some questions answered.(15)

\section{REPARATIONS AND THE LIMINALITY OF THE DEAD}

In the absence of the body and without information, as is the case in so many post-conflict societies, can symbolic processes of closure take place? The projection of liminality of the subject onto a reified image of the deceased in South Africa provides unexpected answers to this question. In South African townships, research has commonly found that survivors projected their own liminality onto an image of those killed violently or disappeared.(16)

The case of Two-Bob Mpofu, although not a political case, demonstrates the link between violent endings and the liminal dead in South Africa. In this case, which received national press coverage, the people of Msogwaba near Nelspruit in South Africa were, according to reports, being haunted by a man who was stabbed to death by his girlfriend in 1993 . The ghost of the deceased, Two-Bob Mpofu, was seen walking around the streets and assaulting passers-by. One man, Thami Mlaba, reported that he was kidnapped by the ghost, assaulted and dumped in the graveyard. The dead man's relatives were particularly prey to his vengeance. The ghost attacked his sister, Nomajele Mpofu, in her home and chased her out of the house. Even a local policeman, Vusi Magagula of the Criminal Investigations Department, claimed to have been assaulted, "I fired several shots at the ghost and emptied my gun, but nothing happened. So I ran away".(17)

A similar phenomenon is also observed in cases of political murder, such as the Sebokeng Night Vigil massacre of 1991, which resulted from a fratricidal war between militarised youth of the rival African National Congress (ANC) and Inkatha Freedom Party (IFP). Margaret Nangalembe is the mother of the murdered ANC comrade Christopher Nangalembe who was allegedly killed by his IFP adversary (and former childhood friend) Victor Kheswa. Nangalembe's night vigil was attacked, allegedly by members of Kheswa's heavily armed gang, who threw hand grenades and fired into the crowd with AK-47s. 42 mourners attending the vigil were killed.(18) At the end of an author interview with Margaret Nangalembe, she broke down and implored, "Why don't people come around to my house like before? They avoid it. They say that the dead are walking around in this 
house, and in the garden."(19)

For Margaret Nangalembe, going to the TRC, testifying in public and receiving reparations was an inchoate attempt to symbolically lay the ghosts of the Sebokeng Night Vigil Massacre to rest. Experiences of liminality demand symbolic recognition, at some level, through public testimony, a memorial or reparations. All reparations (including monetary compensation) are like tombstones - a way of materialising the dead, a way of shifting from the "liminal unknown to the liminal known" (Ramphele, 1996, p. 111). Reparations are therefore a material representation and fixation of memory work, a recognition of the experience of liminality and its objectification in the external world.

Material reparations and compensation serve the same psychological ends as symbolic acts. They are both attempts to ritually create symbolic closure. Financial reparations are often mistakenly viewed as, and spoken about by policy-makers and victims alike, as form of concrete assistance that is different (and certainly more substantial) than symbolic acts such as the erection of tombstones or the naming of streets after the dead. However, the reality is that seldom will the sums of money granted ever equal the actual amount of money lost over the years when a breadwinner is killed, and it is questionable whether the low levels of material reparations offered will dramatically change the life of the recipients. In the South Africa case, material reparation is merely another form of symbolic reparation, albeit particularly welcomed by the destitute survivors for whom any amount of money is appreciated.

When the living receive payment for offences against the dead (and forsake revenge), this can, in some cases, solidify and resolve the dead, who were previously seen as wandering like undead ghosts. Reparations (and processes of remembering and commemoration) stabilise the ghosts, they domesticate and tame them by representing the compensation for their death.

Reparations seem to be one key strategy survivors pursue in order to address their overwhelming feelings of uncertainty. In his essay The Gift, Marcel Mauss asserts that prestations are "total social movements" that are at the same time economic, juridical, moral and psychological phenomena, where "the law of things remains bound up with the law of persons" (Mauss, 1988, p. 2). Material things transferred between people are not inert but contain a spirit of obligation and a part of the giver, that is, "to give something is to give a part of oneself" (ibid., p. 10). The objects exchanged are never completely separate from the people that exchange them and the social context of the exchange, and thus the act of exchange is replete with rights and duties.

Thus, objects are embedded in a social grammar of loss, liminality, closure and responsibility. To this end genuine reparation, and the process of healing, we assert, does not occur through the delivery of the object (for example, a pension, a monument and so 
on) but through the process that takes place around the object.

Mauss is drawing our attention to something very important in the transfer of material objects between people, and that is how persons and things become symbolically equalized and inter-exchangeable. There seems to be an unconscious principle of the transmutability of people and things being played out when the state gives reparations to families of the dead and disappeared. Mauss' discussion of the hau, or the "spirit of the gift" is relevant here, where the hau of reparations is compensation for the spirit of the deceased. The spirit of the dead person and the spirit of the material reparations become exchanged in the transaction between the state and the survivor. The state's obligation to pay reparations results from the duty to repay victims for their sacrifice (in terms of suffering and loss) to the liberation and the construction of the new political order. Victims gave the gifts of their own spirits to 'the community' and the obligation of the new state is to return the gift in the form of reparations to their families.

\section{THE DARKER SIDE OF CLOSURE}

The unconscious associations around reparations are not without their darker connotations, as Mauss has recognised, "The gift is something that must be recognised and that is, at the same time, dangerous to accept" (ibid., p. 58). Reparations place survivors in double-bind situations. Reparations can constitute closure and the final acceptance of loss, but they also can create difficulties for survivors. Some of the Madres of the Plaza de Mayo in Argentina are opposed to monetary reparations, since to accept reparation is to acknowledge death(20). This stands in sharp contrast to the constant rallying cry of the Madres in Argentina, which is "those who were taken from us alive should be returned to us alive." Accepting reparations implies giving up hope that the disappeared would return alive. Similarly, in Brazil, a process of naming streets after the missing (and killed) under the Brazilian dictatorship (1964-1985) has been greeted with ambivalent responses. Some families have been against it because they believe that naming the street concretises the death of their missing relatives. These families appear to still live in hope (or denial) that their children will return and have therefore refused to attend the inauguration of the streets named after their loved ones (see Endnote 4). This refusal also links to feelings of betrayal. Suarez-Orozco argues this is the case for the Madres in Argentina, when he writes:

The Mothers argue that any such bureaucratic intervention requires them to psychologically become their children's executioners: they would first need to psychologically kill and bury their children before proceeding with the legal route. And this is too costly, much too guilt inducing. It is as if giving up hope is betraying their children [Suarez-Orozco, 1991, p. 496].

Perhaps part of their refusal may also involve wanting others to experience the frustration they have felt. They are determined to offer constant reminders that, in reality, there is nothing that can ever be done to replace their missing loved ones. Yet part of the refusal also 
relates to the way in which governments often seek closure on the past more readily than individuals. For survivors, the state's desire to build a new post-conflict society often means sloughing off the past too easily, and asking survivors to engage in a premature closure before all the psychological processes around truth and recompense are fully internalised.

The Madres did not accept the sacrifice of their children or husbands for the new civilian order. They refused to be embodied symbols of the contrast between the old repressive regime and the new benevolent political order. This is read as a vehement rejection of the post-authoritarian regime. This is one reason why government officials and the Argentinean press came to vilify the Madres, who, over the years, have changed from being the 'Mothers of the Nation' to Las Locas or the 'Crazy Little Old Ladies' of the Plaza de Mayo. The recalcitrant Madres were demonized as they no longer embodied the state's vision of a reconciled nation. They persisted in remaining ambiguous when politicians such as former Argentinian President Carlos Menem demanded unity, certainty and closure to bolster a post-authoritarian nation-building project.

Similarly, despite decades having passed since the dictatorship in Brazil, the continuous demands of the Comissão de Familiares de Mortos e Desaparecidos Politicos (Commission for the Family Members of the Persons Killed or Disappeared for Political Reasons) for the truth before compensation, and their refusal to see the new law(21) as the final stop, has made them unpopular. The government and even some previously sympathetic members of society now refer to the group as 'dinosaurs' (Hamber, 1997). They, and the Madres, are seen as imprisoned in the past, as hostages to their own memory and therefore obstructions to the process of selective forgetting advocated by reconciling national political leaders.

The rise and fall of social movements such as the Madres indicates that drawing closure around past violations is an inherently contradictory process that can be expected to take decades. This is the lesson of the French obsession with the war crimes trial of Maurice Papon in 1997, or the rejoicing of many Chileans after the arrest of General Pinochet in a London clinic in late October 1998. Clearly, how to address a history of mass violations is not an issue that will simply be resolved by a two-year truth commission, or when reparations are granted. Reparations and symbolic acts are useful markers in the first stages of recognising and dealing with formerly silenced memory. However, although reparations may well be necessary (and a good starting point) on an individual level, they will never be sufficient. Resolution depends on how individuals personally engage in 'trauma work' at their own idiosyncratic pace.

On a psychological level, for a survivor to react in an overly forgiving way toward perpetrators, or to simply 'let bygones be bygones' in the words of former South African State President FW de Klerk, is highly improbable in the short-term, and even over decades in some cases (Hamber, 1998, p. 68). The South African TRC has been a catalyst for successful resolution of the past for some individuals.(22) However, by the time reparations 
are granted (still outstanding at the time of writing), most survivors will not have completed their trauma work and be willing to adhere to nationally defined prerogatives of remembering and forgetting. It is critical that victims are not expected, either implicitly or explicitly, to forgive the perpetrators, or forget about the past because some form of reparation (or a comprehensive report on the nature and extent of past violations) has been made.

When reparations are granted before the survivor is psychologically ready, any form of reparation can be expected to leave the survivor feeling dissatisfied. When survivors or families of victims disparagingly talk of reparations as a form of blood money (as some do in Chile, Brazil, Argentina and Northern Ireland), this is because the national process of 'reconciliation' does not coincide with the individual psychological process. Reparations and the truth about what happened must be linked, because without this link any form of reparation runs the danger of being seen by the survivors as a governmental strategy to close the chapter on the past prematurely and leave the secrets of the past hidden. Reparations without truth make survivors feel that reparations are being used to buy their silence and put a stop to their continuing a quest for truth and justice.

The long-term and individualised nature of coming to terms with the past is captured by the words of Joyce Mtimkulu, whose son went missing in Port Elizabeth, South Africa in the 1990s. Through the TRC a version of the truth has been revealed. The perpetrators have confessed that her son was tortured, shot, his body burnt and his remains thrown into the Fish River. Despite the emergence of a fairly coherent version of the truth, inconsistencies still exist in the stories of the security police killers, and Mtimkulu remains dissatisfied with what has taken place. After testifying at the hearing and hearing the killers confess, she says:

I have not forgiven them, why must I forgive them when they don't want to tell the truth, and the beauty of this is that they are not asking for forgiveness from us, the people who have lost their beloved ones. They are asking forgiveness from the government, they did nothing to the government, what they did, they did to us [see Endnote 8].

Ignatieff concludes in this case, "Joyce speaks with words of anger, words of grief, truth is not enough, the time for forgiveness has not yet come, the time for reconciliation is in the future" (ibid.).

\section{REVENGE AND PUNISHMENT AS FORMS OF CLOSURE}

We are concerned that the commissioners [of the South African TRC] are critical of efforts to bring to book those who perpetrated crimes against humanity. They think justice is of less value than their reconciliation showbiz and avalanche of tears.(23)

To effectively deal with the impact of large-scale political violence, we need to fully 
comprehend its variegated impact on individuals. National politicians cannot expect individuals to accept their agenda and time schedule for dealing with the past. In particular, they cannot be expected to abandon demands for justice as a form of redress necessary for ending liminality in some cases. This was demonstrated during the Azanian People's Organisation (AZAPO) and the survivors' families of high profile murder cases (Biko, Mxenge and Ribeiro) constitutional challenge in 1996. They challenged section 20(7) of the National Unity and Reconciliation Act, which permitted the TRC to grant amnesty according to certain criteria laid down in the Act. They contested the amnesty provision because, if amnesty is granted, the survivors are denied a right to criminal or civil action against the perpetrator.(24) This constitutional challenge was dismissed by the Constitutional Court in 1996(25), which finally laid aside victims' demands for legal retribution and prosecution for those who were granted amnesty in South Africa.

Although the forgoing of formal justice in South Africa may have been necessary to ensure peace, this national process can run counter to the individual psychological healing process and asks another sacrifice from the victims. This is captured in the words of Archbishop Tutu when he says:

If the security forces had thought that they were going to be up for the high jump we would not have had a negotiated settlement, that is the price that had to be paid, and yes, the victims and survivors are probably asked a second time and to be willing - if this high price had not been paid this country would have gone up in flames.(26)

Indeed the price for the survivors has been high - but how do survivors, given the loss that they have suffered, process this? At the time of significant loss most people enter into a number of invisible pacts with themselves. Sometimes this can be a vow to avenge the death of a loved one, either through formal punishment or personal vengeance. This vow is made, not due to sadistic pleasure, but rather as a way of respecting the person who has died, to make their death and memory meaningful. Individuals also often vow that nothing will ever replace what has been lost.

Revenge, or the infliction of harm in response to perceived harm or injustice (see Stuckless and Goranson, 1994, pp. 803-811), is, according to Michael Ignatieff, commonly regarded as a low and unworthy emotion because its deep moral hold on people is rarely understood (Ignatieff, 1998, p. 188). Ignatieff recognises that revenge is a profound moral desire to keep faith with the dead, to honour their memory by taking up their cause where they left off. To this end, revenge keeps faith between generations and the violence that follows is a ritual form of respect for the community's dead. For Ignatieff, therein lies the legitimacy of revenge.

Nietzsche is one of the few philosophers to have asserted the centrality of revenge in the pursuit of justice, "The spirit of revenge: my friends, that up to now, has been mankind's 
chief concern: and where there was suffering, there was always supposed to be punishment" (Nietzsche, 1969, p. 162). Practically the whole of the rest of western philosophy and jurisprudence has followed Kant and Hegel in denouncing revenge and distinguishing rational law and justice from revenge. The South African TRC has, in the interests of national reconciliation, muted feelings of vengeance and replaced them with what it calls a more restorative model.(27) As a result of national imperatives, survivors have generally felt inhibited in expressing their legitimate rage and anger, and demanding just retribution. Erich Fromm feels that vengeance (revenge) is in some senses a magic act and, like punishment for a crime, it can serve the function of magically expunging the perpetrators' act (Fromm, 1984, p. 364). Fromm links vengeance directly to reparation; vengeance is said to be a magical reparation. In this way, like reparations, we contend that revenge and punishment (and perhaps the fantasies thereof) can also be a way to lay the ghosts of the violently killed to rest and end the liminal status of the victim and survivor.

Furthermore, if the desire for vengeance grips the survivor, then accepting paltry reparations can also be experienced by the survivor as a disrespectful act that betrays the loss they have endured or the memory of those killed. In essence, rituals of respect (such as retribution through the courts) and remembering can be broken by reparations, just as they can in some cases serve as a symbol of mending.

The difficulties of coming to terms with the aftermath of political trauma for the individual have to be acknowledged. Coming to terms with the past can only be eased by recognising as legitimate the multiple and contradictory agendas which exist among a heterogeneous community of survivors. The demands of some survivors for retributive justice need to be seen as just as legitimate a path to 'reconciliation' as forgiveness. Public and private space needs to be made to enable them to rework their diverse memories of past conflicts and feelings of anger. Contained, yet legitimate, revenge and punishment feelings are obviously more desirable than acted-out fantasies.

A state-led process of substantial and personalised symbolic, material and collective reparations also needs to be set in motion. This did not occur in the South African context, where reparations were very low on the list of priorities of national politicians, and a compensation scheme for the majority of victims had not been established at the time of writing, over a year after the TRC's report was published. In January 2000, the Mbeki government stated its intention to offer only token compensation of a few hundred pounds (Rands 2000), instead of the $£ 15000$ which the TRC recommended should be given to 22000 victims of apartheid. Duma Khumalo spoke for many victims when he protested bitterly, 'We have been betrayed. The previous government gave the killers golden handshakes and the present government gave them amnesty. [But] the victims have been left empty handed ['Apartheid Victims Reject Handouts' Guardian. 3 January, 2000].' 


\section{CONCLUSION: WHERE DWELL THE VAST HOSTS OF THE DEAD?}

His soul had approached the region where dwell the vast hosts of the dead. He was conscious of, but could not apprehend, their wayward and flickering existence. His own identity was fading into a grey impalpable world: the solid world itself which these dead had one time reared and lived in was dissolving and dwindling (James Joyce in his short story entitled The Dead).

The process of breaking a regime of denial, addressing and recognising repressed memories, compensating for loss, and ultimately arriving at some type of closure and reintegration of liminal subjects, works at different levels, i.e. individuals, truth commissions, and criminal prosecutions. There are different motivations at these different levels, and they proceed at different paces. There is not a single process of dealing with the past that restores the 'national psyche' to good health. We have rejected the idea of the collective as an extrapolation of the individual as a myth of nation-building. Instead, we have drawn attention to the disjunctures, as well as the convergences, between individual responses and national institutions. National processes such as truth commissions (although by no means the only process) can provide a useful framework in which new rituals or spaces can be provided for the enactment of closure.

Strategies such as truth commissions, Fiona Ross argues, are performances of memory that create a framework of explanation (Ross, 1997, p. 9). Ross (ibid., p. 10) quotes Jack Kugelmas' formulation that memory is a process of both remembering and forgetting. Facts need a narrative framework in order to be rendered meaningful and take their place in a shared account of the past. Where there is no accessible literature of destruction, performance (rituals) are means to bridge what he calls the "fundamental discontinuities of life". To this end, Ross argues that through the South African TRC:

South Africa is currently witnessing a process of shifting a new framework of description and definition into place, creating, if not a cohesive narrative of past pain, then at least the beginnings of a framework within which moralities can be placed and debated...The framework is contested. Indeed, that is the strength of the commission's process...It gives visible and tangible shape to the past, providing, shall we say, a ritual context within which the past can be examined and placed on record - at least in part [ibid.].

Governmental strategies like truth commissions can create the public space for survivors to begin the process of working through a violent and conflicted history. Of course they are also not the only means. For any strategy for dealing with the past to be successful, an ongoing space has to be provided for survivors to express both their grief and their rage, as they struggle to come to terms with the inherent ambivalences of the psychological and emotional impact of their loss - a loss that reparation and even the truth can only partially acknowledge. It is how the individual processes the symbolic meaning of the ritual, the 
reparation or a national process such as a truth commission, that is critical. For this reason, making space for the legitimate complaints and opposition of survivors should be seen as an integral component of dealing with the past. These spaces can take the form of private spaces (for example, counselling, culturally appropriate mechanisms for story-telling and sharing, and so on) and the ongoing use of public space (for example, media, exhibitions, theatre, and so on).

At a national level, this means recognising publicly that the past is a site of struggle, not a fixed object to which all members of the nation must identify. As Antze and Lambek write, "Memory becomes a locus of struggle over the boundary between the individual and the collective or between distinct interest groups in which power becomes the operative factor" (Antze and Lambek, 1996: xx). In this context, the analysis of trauma work in post-conflict situations involves the charting of the dynamic between national appropriations of memory and individual resistance and acquiescence.

In addition, the calls for punishment of perpetrators (even when this is not pragmatically possible), or the impossible demands of survivors like those of the Madres, need to be understood as rituals of closure in themselves. These calls can re-establish the discontinuities in time for the survivor; that is, they survived, their loved ones did not and will not ever appear again. In post-conflict societies, angry calls for justice and revenge persist until the process of trauma work and reintegration is resolved. The rituals which national polities put into place both hinder and promote individual psychological processes of recovery. Recognizing the diversity of responses to suffering (including anger and vengeance) ensures that the demanding and inherently ambivalent psychological processes of grieving the dead are not wholly appropriated by post-conflict societies using narrow Christian and human rights discourses of reconciliation and nation-building.

Truth commissions do not heal the nation, restore the collective psyche or categorically deal with the past. Their value is much more limited and constrained, and lies in creating a public space in which publicly telling subjective truths, which are but one form of closure among many, may occur. They may also cause further psychological trauma when individuals (such as widows) are treated as the social embodiment of the nation, and are expected to advance at the same pace as the state institutions which are created in their name, but which are primarily pursuing a national political agenda.

\section{Notes}

(1) Space does not permit a thorough discussion of the nature, mandate and structure of the Truth and Reconciliation Commission. For more detail, see: Asmal, K., Asmal, L. and 
Roberts, R. S., 1996; Burton, M., 1998; Hamber, B. and Kibble, S., forthcoming; Simpson, G. and van Zyl, P., 1995; Wilson, R. 2000. For the full mandate of the TRC, see the full text of the Promotion of National Unity Act, No. 34 of 1995, at

http://www.truth.org.za/legal/act9534.htm

(2) For a more detailed discussion of the reparations issue in South Africa, see: Hamber, B., 1998: http://www.incore.ulst.ac.uk/publications/conference/thepast/repair.html

Also see the TRC's Reparation and Rehabilitation Policy in the TRC Final Report, Volume 5 , Chapter 5 .

(3) Within this chapter we use the TRC's definition of reparation, which can include measures in the form of compensation, an ex gratia payment, restitution, rehabilitation or recognition. To this end our notion of reparation is very broad and not only includes monetary compensation but also incorporates a range of other reparation strategies. These include the need for symbolic reparations (for example, erecting headstones, the building of memorials, and so on), legal and administrative interventions (for example, expunging criminal records or the issuing of declarations of death), as well as community reparations (such as programmes for better access to health).

(4) Cecilia Coimbra from Grupo Tortura Nunca Mais (Rio de Janeiro), Interview with Brandon Hamber, December 1996, Rio de Janeiro. For a fuller discussion on the families in Brazil, see: Hamber, B., 1997.

(5) There are more than 20 bodies unaccounted for in Northern Ireland, most said to be Catholics killed by the Republican groups and the (Provisional) Irish Republican Army or the IRA. The IRA have acknowledged that 12 of the people abducted and killed between 1972 and 1980 were activities committed under its command. See The Irish Times, June 26, 1998, Front Page.

(6) Sandra Peake, Co-ordinator of the WAVE Counseling Centre, Interview with Brandon Hamber, 27 October, 1998, Belfast.

(7) William McKinney, The News Letter, August 14, 1998, p. 2. William McKinney's son, Brian, disappeared in 1978 after being abducted by Republicans in West Belfast.

(8) Joyce Mtimkulu, Interview with Michael Ignatieff, "Getting Away with Murder", Special Correspondent Programme, BBC2. Joyce Mtimkulu is the mother of Siphiwo, who went missing in South Africa a decade and a half ago.

(9) For a study of these events in Argentina, see: Malin, A., 1994. 
(10) For a discussion of Freud, trauerarbeit and the history of the Holocaust, see Santner, E., 1992.

(11) Susan van der Merwe, Testimony at the TRC hearings, Klerksdorp, 23 September, 1996.

(12) The military wing of the African National Congress (ANC).

(13) The Madres emerged as an important democratising social movement during Argentina's military dictatorship of the late 1980s. These mothers of the disappeared began by marching around the Plaza de Mayo in Buenos Aires, demanding the return of their sons and daughters taken by the military's death squads.

(14) See comments by the families of the disappeared in the Irish Times, August 31, 1998, p. 6; The News Letter, August 14, 1998, p. 6; the Irish Times, June 26, 1998, Front Page; and the statement issued on behalf of the relatives of the disappeared on September 7, 1998.

(15) For a discussion on the importance of truth in the Northern Ireland context, see: Hamber, B., 1998 and Rolston, B. 1996.

(16) This was confirmed by interviews conducted by Richard Wilson in the Vaal townships of Sebokeng, Sharpeville and Boipatong, from 1996 to 1998.

(17) "Stabbed man's ghost haunts our village", report Eric Mashaba and Sylvester Lukhele, Sunday Times, 29 September, 1993.

(18) Newspaper reports are inconclusive on the exact number of people killed in the incident, reports ranging from 39 to 46 fatalities. 42 is the figure used by the Nangalembe family and is therefore the number used in this chapter.

(19) Margaret Nangalembe, Interview with Richard Wilson, 29 November 1996, Sebokeng, South Africa.

(20) In Argentina two main groups exist. The Madres de la Plaza de Mayo reject all government attempts to investigate the truth and only want justice. This group split with the Madres de la Plaza de Mayo - Linea Fundadora in 1986. The Madres de la Plaza de Mayo - Linea Fundadora, despite initially being against all investigations and truth recovery processes, now work with the government in investigating disappearances (for example, exhumations) and accept the reparations offered. See Hamber, B., 1997.

(21) The issue of compensation has only recently been thrust into main focus when the government agreed in 1995 to compensate the families of the murdered and 'disappeared', 
in some cases two decades after the 'disappearances'. The bill was approved by the Brazilian Congress in September 1995. 136 names of disappeared persons were officially acknowledged by the government. The number of those considered dead or disappeared is still contested by some of the families of victims in Brazil. The onus is however on the families to prove the government was responsible. The group sees this as the government's final attempt to buy their silence and close the book on the past, without revealing the true facts of what happened during the military dictatorship.

(22) For a discussion of several cases where there has been forgiveness between victim and perpetrator in South Africa, see: Frost, B., 1998 as well as the TRC Final Report, Volume 5, Chapter 5: "Reconciliation".

(23) Azanian People's Organisation (AZAPO) chair in Guateng, Lybon Mabaso, telling a Johannesburg news conference that the TRC was defeating the ends of justice by attempting to stop the attorney-general from pursuing apartheid-era human rights offenders. In "The Truth as it was Told", Weekly Mail and Guardian, 23 December, 1997.

(24) Azanian People's Organisation (AZAPO) and Others v. the President of the Republic of South Africa, 1996.

(25) In sum, the judgement largely argues that amnesty was necessary and pragmatic to ensure democracy in South Africa, and that hopes for large-scale prosecution were not viable given the inefficiencies of the court system. It argues that the TRC offered at least potentially some truth and reparations to a greater number of survivors than the courts would have. The courts would have offered this to fewer people although the civil claims would have undoubtedly been larger than the reparations that may be made available through the TRC. Despite the upholding of the amnesty provisions, the judgement makes it clear that because perpetrators will be granted amnesty, those found to be victims are entitled to 'individually nuanced' reparations. Nonetheless, the judgement makes an important rejoinder to this argument, that is, the state can take into consideration the available resources, the claims of all victims and the competing demands of the government when deciding what reparation policies to implement. See South African Journal of Human Rights, 13(2), which has several papers dealing with this ruling.

(26) Archbishop Desmond Tutu, Interview with Michael Ignatieff, "Getting Away with Murder", Special Correspondent Programme, BBC2.

(27) To some degree, the TRC can be said to embody restorative justice principles at a national level; however, it is argued that it does not wholly embody the principles of restorative justice at an individual level. This is because victims in the TRC scenario still do have the individual capacity to effect the outcome of the amnesty process, and that reparation is made from the state. There is no obligation on the perpetrator to make direct 
amends or offer restitution to the victim in the TRC model. See Hamber, B. and Kibble, S., forthcoming. Also see Zehr, H., 1997: 20.

\section{REFERENCES}

South African Journal on Human Rights, 1997, 13(2).

Antze, P. and Lambek, M. (eds.). Tense Past: Cultural Essays in Trauma and Memory. London: Routledge, 1996.

Archbishop Desmond Tutu. "Getting Away with Murder." Interview with Micheal Ignatieff, Special Correspondent Programme, BBC2.

Asmal, K., Asmal, L., and Roberts, R. S. Reconciliation Through Truth: A Reckoning of Apartheid's Criminal Governance. Cape Town: David Roberts Publishers, 1996.

Azanian People's Organisation (AZAPO) and Others v. the President of the Republic of South Africa CCT 17/96, Constitutional Court, 25 July 1996.

Bronkhorst, D. Truth and Reconciliation: Obstacles and Opportunities for Human Rights. Amsterdam: Amnesty International, 1995.

Burton, M. "The South African Truth and Reconciliation Commission: Looking Back, Moving Forward - Revisiting Conflicts, Striving for Peace." In B. Hamber (ed.), Past Imperfect: Dealing with the Past in Northern Ireland and Societies in Transition. Derry / Londonderry: University of Ulster / INCORE, 1998.

Fromm, E. The Anatomy of Human Destructiveness. Great Britain: Penguin Books, 1984.

Frost, B. Struggling to Forgive: Nelson Mandela and South Africa's Search for Reconciliation. Great Britain: Harper Collins Publishers, 1998.

Hamber, B. Do Sleeping Dogs Lie? The Psychological Implications of the Truth and Reconciliation Commission in South Africa. Seminar Paper No. 5. Johannesburg: The Centre for the Study of Violence and Reconciliation, 1995.

Hamber, B. "Living with the Legacy of Impunity: Lessons for South Africa about Truth, Justice and Crime in Brazil." Unisa Latin American Report, 13(2), 4-16. Pretoria: Unisa Centre for Latin American Studies, University of South Africa, 1997.

Hamber, B. "Remembering to Forget: Issues to Consider when Establishing Structures for Dealing with the Past." In B. Hamber (ed.), Past Imperfect: Dealing with the Past in Northern 
Ireland and Societies in Transition. Derry / Londonderry: University of Ulster / INCORE, 1998.

Hamber, B. "Conclusion: A Truth Commission for Northern Ireland?" In B. Hambert (ed.), Past Imperfect: Dealing with the Past in Northern Ireland and Societies in Transition. Derry / Londonderry: University of Ulster / INCORE, 1998a.

Hamber, B. "Repairing the Irreparable: Dealing with Double-Binds of Making Reparations for Crimes of the Past." Paper presented to the African Studies Association of the UK, London, Sept. 1998b. (Updated Version forthcoming, Social Science and Medicine)

[http://www.incore.ulst.ac.uk/publications/conference/thepast/repair.html]

Hamber, B., and Kibble, S. From Truth to Transformation: South Africa's Truth and Reconciliation Commission. Briefing Paper. London: Catholic Institute for International Relations (CIIR), forthcoming.

Hayes, G. "We Suffer our Memories: Thinking about the Past, Healing and Reconciliation." American Imago, 1998, 55(1).

Ignatieff, M. The Warrior's Honor: Ethnic War and the Modern Conscience. London: Chatto \& Windus, 1998.

Ignatieff, M. Narration in the documentary Getting Away with Murder. Special Correspondent Programme, BBC2.

Janoff-Bulman, R. "The Aftermath of Victimisation: Rebuilding Shattered Assumptions." In C. R. Figley (ed.), Trauma and its Wake. New York: Brunner Mazel Publishers, 1985.

Jelin, E. "The Minefields of Memory." NACLA Report on the Americas, Report on Memory, 33(2), 1998.

Lapsley, M. "Healing the Memory: Cutting the Cord Between Victim and Perpetrator Interview with Father Michael Lapsley by Hannes Siebert." Track Two, 1997, 6(3 \& 4), p. 46.

Malin, A. "Mothers Who Won't Disappear." Human Rights Quarterly, 1994, 16(1), 187-213.

Mashaba, E. and Lukhele, S. "Stabbed Man's Ghost Haunts Our Village." Sunday Times, Sept. 29, 1993.

Mauss, M. The Gift: Forms and Functions of Exchange in Archaic Societies. London: Routledge, 
1998.

Mtimkulu, J. "Getting Away with Murder." Interview with M. Ignatieff, Special Correspondent Programme, BBC2.

Neal, A. G. National Trauma and Collective Memory: Major Events in the American Century. New York \& London: M. E. Sharpe, 1998.

Nietzsche, F. Thus Spoke Zarathustra. London: Penguin, 1969.

Pauw, B. A. 1990. "Widows and Ritual Danger in Sotho and Tswana Communities." African Studies, 49(2).

Ramphele, M. "Political Widowhood in South Africa: The Embodiment of Ambiguity." Daedalus, 1996, 125(1), 99-117.

Rolston, B. Turning the Page without Closing the Book: The Right to Truth in the Irish Context. Dublin: Irish Reporter Publications, 1996.

Ross, F. "Blood Feuds and Childbirth: The TRC as Ritual." Track Two, 1997, 6(3 \& 4).

Santner, E. "History Beyond the Pleasure Principle." In S. Friedlander (ed.), Probing the Limits of Representation: Nazism and the Final Solution. Cambridge, MA: Harvard University Press, 1992.

Simpson, G., and van Zyl, P. South Africa's Truth and Reconciliation Commission. Occasional Paper. Johannesburg: Centre for the Study of Violence and Reconciliation, 1995.

Stuckless, N. and Goranson, R. "A Selected Bibiliography of Literature on Revenge." Psychological Reports, 1994, 75, 803-811.

Suarez-Orozco, M. "The Heritage of Enduring a Dirty War: Psychological Aspects of Terror in Argentina." The Journal of Psychohistory, 1991, 18(4), 469-505.

Wilson, R. 2000. The Politics of Truth and Reconciliation in South Africa: legitimizing the postapartheid state. Law and Society Series. Cambridge: Cambridge University Press.

Zehr, H. "Restorative Justice: When Justice and Healing Go Together." Track Two, 1997, $6(3 \& 4)$. 


\section{Authors}

Brandon Hamber is a Clinical Psychologist and co-ordinator of the Transition and Reconciliation Unit at the Centre for the Study of Violence and Reconciliation, Johannesburg, South Africa. Visiting Tip O'Neill Fellow at the Initiative on Conflict Resolution and Ethnicity (INCORE) in Derry, Northern Ireland. He has written widely on the Truth and Reconciliation Commission and the psychological parameters thereof. He has edited the book Past Imperfect: Dealing with the Past in Northern Ireland and Societies in Transition (University of Ulster / INCORE). Email: mail@brandonhamber.com Centre for the Study of Violence and Reconciliation, P.O. Box 30778, Braamfontein, 2017, Johannesburg, South Africa. Tel: +27 (11) 403-5650 Fax: +27 (11) 339-6785.

Richard Wilson is Gladstein Chair of Human Rights and Director of the Human Rights Institute at the University of Connecticut. He is the author of numerous works on political violence and social movements in Guatemala, including the book Maya Resurgence in Guatemala (1995). He has edited or co-edited four books; Low Intensity Democracy: political power in the new world order (1993) Human Rights, Culture and Context (1997), Culture and Rights (2001) and Human Rights in Global Perspective (2003). His research on questions of memory, truth and justice and the South African Truth and Reconciliation Commission led to the monograph The Politics of Truth and Reconciliation in South Africa (2001, Cambridge University Press). He has been a visiting Professor at University of Oslo, New School for Social Research and University of the Witwatersrand and acted as a consultant on human rights issues for UNICEF, the British government and non-governmental organizations such as Conciliation Resources. Presently he is writing about the International Criminal Tribunal for the Former Yugoslavia and the International Criminal Court. He is associate editor of the journal Anthropological Theory and on the editorial boards of Critique of Anthropology and the Journal of Human Rights. His email is

richard.wilson@uconn.edu 